\title{
EDUCATED AND SATISFIED WORKER - FOUNDATION OF MODERN AND SUCCESSFUL COMPANY
}

\author{
Snežana LEKIĆ ${ }^{1}$, Srđan BOGETIĆ ${ }^{2}$, Marijana VIDAS BUBANJA ${ }^{1}$ \\ ${ }^{1}$ Belgrade Business School, 11000 Belgrade, Kraljice Marije 73, Republic of Serbia \\ ${ }^{2}$ Belgrade Business School, 11000 Belgrade, Kraljice Marije 73, Republic of Serbia \\ E-mail: srdjan.bogetic@bbs.edu.rs
}

UDC: $005.32: 331.101 .3$

Original Scientific Paper

Paper received: 21.05.2013.; Paper accepted: 19.11.2013.

\begin{abstract}
Modern business work and processes are technology intensive and they require educated and quality work force. Priority aim of human resource management today is to attract and keep those workers who can mostly contribute to successful and competitive company work with their knowledge and skills. This paper analyzes factors that determine quality level of workers contribution with the focus on job satisfaction. Job satisfaction is complex attitude encompassing assumptions about work, beliefs, quality assessments. The following effects are results of job satisfaction: 1) productivity rise, 2) workers are more devoted to their obligations and tasks and 3) they are less absent from their work. Recent research results show job satisfaction is influenced by factors such as: gender, age, education level, working experience, working conditions, salaries, working time and promotion. The aim of empirical examination in this paper is to assess the satisfaction level of workers in the sample and to identify factors that contribute to professional satisfaction with the final aim to assess effects of job satisfaction on successful and competitive company work.
\end{abstract}

Key words: human resource, job satisfaction, competitive advantage, education, working skills.

\section{INTRODUCTION}

Job satisfaction refers to the general attitude of an individual in relation to his work. It can be defined as "the cognitive, affective and evaluative responses of an individual to his job." (Greenberg and Baron, 1998) Job satisfaction is complex attitude encompassing certain assumptions and beliefs about work (cognitive component), feelings towards work (affective component) and evaluation of work (evaluative component). Job satisfaction is one of the most researched topics in the field of human behavior in organizations. It is considered that a satisfied employee is a productive employee, and that the success of an organization cannot be achieved with dissatisfied employees.

The issue of employee satisfaction with the work of their organizations dealt with the American magazine Fortune, who has been ranking The Best Companies to Work For since 2006 . When we look at Table 1. we see companies none of which are in the top twenty of the best and most profitable companies in the world. The list includes companies whose business motto is to have the pleasure of workers organization in which they work as a prerequisite for successful business. Google has entered the list of Fortune magazine as early as 2007, when it was first on the list, and ever since has been in the first four companies in which employees are satisfied with their work.

Statistics showed that all of these companies have a steady increase in new jobs, where an example can take the company Hilcorp Energy Company with a $48 \%$ job growth over the previous year. The reason for interest in working for companies that are on the list is the fact that they pay attention to the motivation of employees through a variety of ways:

- Concern about the mental and physical state of employees and as such it takes a company Google, which in 2013 opened up a large 
fitness center where employees can be free of charge to recreate or relax through free hour massage.

- If employees have too much overtime (BCG) they give employees the opportunity for six monthly volunteer works with financial compensation for their work.

- Encouraging creative thinking among employees.
- Caring for feeding of employees through the consumption of organic food in the company cafeteria.

- Financial incentives to overthrow the annual rate.

- Creating security for the employees of the company by offering social and medical support

Table 1: Best Companies to Work For

\begin{tabular}{|c|l|c|c|}
\hline Rank & Company Name & Job Growth & No. of Employees \\
\hline 1. & Google, Inc (1) & N.A. & 34.311 \\
\hline 2. & SAS (3) & $5.6 \%$ & 6.373 \\
\hline 3. & CHG Healthcare Services (9) & $4.7 \%$ & 1.378 \\
\hline 4. & The Boston Consulting Group (2) & $18.6 \%$ & 2.314 \\
\hline 5. & Wegmans Food Markets (4) & $8.3 \%$ & 43.927 \\
\hline 6. & NetApp (6) & $7.8 \%$ & 7.426 \\
\hline 7. & Hilcorp Energy Company & $47.7 \%$ & 1.012 \\
\hline 8. & Edward Jones (5) & $-0.9 \%$ & 35.114 \\
\hline 9. & Ultimate Software (25) & $18.7 \%$ & 1.440 \\
\hline 10. & Camden Property Trust (7) & $13 \%$ & 1.896 \\
\hline
\end{tabular}

(source: http://money.cnn.com/magazines/fortune/best-companies/?iid=bc_sp_header)

These are just some of the ways to motivate employees by the successful company, and as a result lead to employee satisfaction and sense of security work in these companies. Also, in Table 1 we can see that almost all enterprises have shown business growth. What is even more important is the fact that these companies receive many work applications, yet only a few are privileged to be employed.

The analysis of human resources has to cover several elements, of which a particular focus should be on motivation and its influence on organizational commitment. Reasons for a big interest in motivation problem are reflected in increasing productivity, efficiency and work creativity, improvement of working conditions in organisations, as well as growing of competitive ability and successfulness of enterprises (Lekić, S., Bogetić, S., Ranđić, D., p. 678).

\section{THEORETICAL BASES OF JOB SATISFACTION RESEARCH}

Theoretical bases of job satisfaction can be found in Locke's theory of value (Greenberg and Baron, 1998). According to this theory, job satisfaction exists in the extent to which people are satisfied with the outcome of the job itself. The more an individual benefits from the outcome, the more he will be satisfied. Not only does the size of a reward have an effect on job satisfaction, but the received reward as well. According to this theory, employees with low wages need not be unsatisfied if their salary is not the most important factor in job satisfaction. Anticipating job satisfaction of an individual, we must take into account not only the satisfaction of certain aspects of a job in which an individual is engaged in, but also his expectations from this job. Discrepancy or deviation from the expected satisfaction regarding certain aspects of a job affects the overall job satisfaction but not the amount of satisfaction itself. Locke's theory draws attention to another important phenomenon. People have a tendency to associate the amount of satisfaction with certain aspects of a job with the amount of discrepancy between expectations and satisfaction. In those aspects where the discrepancy between expectations and satisfaction is high, the absolute amount of satisfaction tends to decline. Studies have shown that employees were most dissatisfied with those aspects of a job where there was greatest discrepancy and vice versa.

The theory of value is important because it emphasizes the aspects of a job that need to be changed so that people are more satisfied with it. It emphasizes the fact that these issues may not be the same for all people, but it can be any aspect of a job where people perceive serious discrepancy. Emphasizing values, Locke's theory suggests that job satisfaction depends on various factors that can be grouped into two categories: organizational and personal factors of job satisfaction (Robbins, 2003). Organizational factors of job satisfaction are job itself, the reward system, pleasant working 
conditions, colleagues, organizational structure. Personal factors of job satisfaction are: balance between personal interests and work, work experience and age, position and status, overall life satisfaction.

\section{EDUCATED AND SATISFIED WORKER}

In contemporary global business conditions, companies are faced with increasing competition and demand for flexibility and continuous business improvement. In such business environment, modern companies must acknowledge the fact that technological and business capital depends on human capital - working skills, education, relevant experience, and career development. Also, the educational level of the work force is directly correlated with the ability to assess the factors that determine job satisfaction of employees and their good performance.

Depending on the company strategies towards human resource potential, the consequences of contemporary work techniques may be reasonable in relation to downsizing, retraining of those that are made redundant, employing new personnel compatible with the demands of new technology and similar, or negative - resistance, noncooperation and dissatisfaction.

The acceptance period of the contemporary business and technological changes in the company, and the reactions to it must be accompanied by adequate management, to ensure that personnel motivation and its productivity are not significantly affected, reduced or compromised. A significant issue in relation to this is certainly the issue of education because flexibility and adaptability are becoming major determinants of an organization, and of the work force.

Regarding the fact that many jobs are disappearing, and for the new ones different skills and knowledge's are required, the company must take this into account and must make plans within its personnel policy and it has to fit the activities of education of existing personnel as well as to provide activities of scholarships for those personnel that may become scarce. Unfortunately, there are few companies that can simultaneously develop plans for their human capital and work on plans that predict changes in the types of jobs, the required workforce and education of the existing workforce, and to set aside enough money for socalled permanent education of the personnel, who will be able to meet the challenges of new technology.

In addition to adequate education policy at all levels of a company, education and training system in the country is of great importance. Whether the employees can acquire new knowledge in accordance with the development of modern management techniques or the fact how educated young employees who have just finished their schools are depends on the school system and education in the country. The quality of the education system of the country and the efficiency of labor market institutions that will quickly divert and re-qualify their workers, largely determines the impact of new technologies and management practices in the human resources of the country (Vidas-Bubanja, 2005). The answer, of course, lies in the education system of the country. Germany, for example, is known for its intensive training of young workers during their high school education, while Sweden has developed a system of training of unemployed workers, on the basis of social programs to seek new jobs for laid-off workers.

Education and training is becoming an integral part of every job. The following axioms in the field of human resources management in the 21 st century are considered (Vidas-Bubanja, 2007):

- continuing education is essential and mandatory for employees and employers;

- information technology affects all jobs - no one is safe, nor can its impact be ignored;

- change is normative;

- work is highly interdependent in terms of business, in terms of communication and transport in different areas of activity;

- there is no standard way on the career ladder and progress.

These transformations of the workforce usually do not follow the requirements of technology at its own pace, so there is a resistance, or transfer to other companies and other countries. How much is knowledge becoming an important factor of development is best shown in the examples of companies which change its structure and policy towards continuous learning and continuous improvement in order to be successful. Knowledge management is becoming a primary concern. Companies that want to remain competitive not only provide training and learning at all levels, but often organize activities for their own universities. 


\section{EMPIRICAL STUDY OF JOB SATISFACTION IN SERBIA}

At a time when Serbia is undergoing a period characterized by economic instability and high unemployment, the survey of job satisfaction in local companies represents a challenge which should enable the determination of the factors that have a critical influence on satisfaction and on the productivity of the local workforce as well. The study of job satisfaction is part of a larger study concerning the effects of organizational behavior on organizational commitment (Lekić, 2010). In the transition process individual business subjects should be capable for operating on the market, which is based on market approach, profit as basic drive of business activities and dominance of private property. In the stage of economic transition enterprises have to be capable to run a successful market game on a global level (Bogetić, S., Ranđić D., p. 354). The aim of the research was to assess the job satisfaction of workers included in the sample, and to identify the factors that contribute to professional satisfaction with the ultimate aim of reviewing the effect of employee's satisfaction on the success and competitiveness of business.

The study included: two public companies (PUC "Beograd put" and The Public Company of PTT Communications "Srbija"), a higher education institution (Belgrade Business School-Higher Education Institution for Applied Studies) owned by the State according to its structure of property, and several small private companies that have not been segmented, but due to the limited space in the paper tagged as "Other companies". Of the total number of respondents (N492), PUC "Beograd put" (hereinafter referred to as Beograd put)had 219 participants $(44.51 \%)$, the Public Company of PTT Communications "Srbija" (herinafter referred as PC of PTT) $141(28,66 \%)$, Belgrade Business School-Higher Education Institution for Applied Studies(herein referred as Belgrade Business School) $54(10,98 \%)$ while in the group of other companies the sample included 78 employees $(15,85 \%)$.

To measure job satisfaction, an adapted questionnaire of job satisfaction was used (Gregson, 1987). Measuring job satisfaction was carried out using the model for measuring satisfaction of the employees at the level of the company which is based on the examined (measured) dimensions of employee's satisfaction as follows: c1 - satisfaction with earnings, c2 satisfaction with the cooperation with closest associates, c3 - Satisfaction with the possibility of advancement in the hierarchy, c4 - satisfaction with the system of rewarding stimulus, c5 satisfaction with cooperation and relations with superiors, and c6 - satisfaction with job contents. The point is to find the average relative score in the survey regarding the particular dimensions of the overall satisfaction of the employees.

In this part of the study measuring parameters of satisfaction by applying the analysis of variance and regression was used (Christensen, 1996). In assessing the satisfaction of certain parameters in the study the following Likert scale with five possible answers is used: 1 - very dissatisfied, 2 unsatisfied, 3 - satisfied, 4 - fairly satisfied, 5 very satisfied.

Employees' satisfaction is evaluated on the basis of the six different sizes $\left(c_{\mathrm{ji}}\right)$ and the coefficient of satisfaction of individual employee receives as:

$$
\mathrm{SZ}_{\mathrm{i}}=\frac{\left(\mathrm{c}_{1 \mathrm{i}}+\mathrm{c}_{2 \mathrm{i}}+\mathrm{c}_{3 \mathrm{i}}+\mathrm{c}_{4 \mathrm{i}}+\mathrm{c}_{5 \mathrm{i}}+\mathrm{c}_{6 \mathrm{i}}\right)}{6}
$$

where: ${ }_{\mathrm{i}}=1, \ldots, \mathrm{n}$; while $\mathrm{n}$ stands for the total number of employees.

This coefficient shows the average value of employee's satisfaction based on the evaluated (rated) six dimensions. For the analysis of satisfaction of employees at the company's level as a whole, the average value of these dimensions of satisfaction are taken, on the basis of which the coefficient of employees'satisfaction in the whole company is provided as:

$$
\mathrm{SZ}=\frac{\left(\mathrm{c}_{1}+\mathrm{c}_{2}+\mathrm{c}_{3}+\mathrm{c}_{4}+\mathrm{c}_{5}+\mathrm{c}_{6}\right)}{6}
$$

while:

$$
\mathrm{c}_{\mathrm{j}}=\frac{\sum_{i=1}^{n} \mathrm{c}_{\mathrm{ij}}}{\mathrm{n}},(\mathrm{j}=1, \ldots, 6)
$$

Based on these relations the matrix of employees from different companies is made, in other words, their evaluation from individual dimensions of satisfaction. Then the average evaluation of total job satisfaction for the whole sample is determined, as well as for the individual companies included in this research. Total job satisfaction is shown in Table 2. 
By using the covariance matrix of different parameters of job satisfaction, correlation coefficients of evaluation of various parameters were calculated. Covariance matrices of evaluations from different satisfaction parameters are given in Table 3.

Table 2: Total job satisfaction

\begin{tabular}{|c|c|c|c|c|c|c|c|}
\hline Company & $\mathbf{c}_{\mathbf{1}}$ & $\mathbf{c}_{\mathbf{2}}$ & $\mathbf{c}_{\mathbf{3}}$ & $\mathbf{c}_{\mathbf{4}}$ & $\mathbf{c}_{\mathbf{5}}$ & $\mathbf{c}_{\mathbf{6}}$ & $\mathbf{S Z}$ \\
\hline PC “Beograd put” & 2,91 & 3,23 & 2,82 & 2,78 & 3,05 & 3,09 & $\mathbf{2 , 9 8}$ \\
\hline PC “PTT" & 2,27 & 3,29 & 2,53 & 2,26 & 3,30 & 3,05 & $\mathbf{2 , 7 8}$ \\
\hline Belgrade Business School & 3,83 & 3,78 & 3,65 & 3,56 & 4,02 & 3,85 & $\mathbf{3 , 7 8}$ \\
\hline Other Companies & 2,88 & 3,32 & 2,80 & 2,40 & 3,35 & 3,31 & $\mathbf{3 , 0 1}$ \\
\hline Whole sample & 2,82 & 3,32 & 2,82 & 2,66 & 3,28 & 3,19 & $\mathbf{3 , 0 2}$ \\
\hline
\end{tabular}

Table 3: Covariance matrices of evaluations from different parameters of job satisfaction

\begin{tabular}{|l|c|c|c|c|c|c|}
\hline & $\mathbf{c}_{\mathbf{1}}$ & $\mathbf{c}_{\mathbf{2}}$ & $\mathbf{c}_{\mathbf{3}}$ & $\mathbf{c}_{\mathbf{4}}$ & $\mathbf{c}_{\mathbf{5}}$ & $\mathbf{c}_{\mathbf{6}}$ \\
\hline $\mathbf{c}_{\mathbf{1}}$ & 1,154 & 0,490 & 0,692 & 0,777 & 0,565 & 0,518 \\
\hline $\mathbf{c}_{\mathbf{2}}$ & 0,490 & 0,894 & 0,503 & 0,509 & 0,592 & 0,496 \\
\hline $\mathbf{c}_{\mathbf{3}}$ & 0,692 & 0,503 & 1,053 & 0,839 & 0,588 & 0,553 \\
\hline $\mathbf{c}_{\mathbf{4}}$ & 0,777 & 0,509 & 0,839 & 1,197 & 0,658 & 0,565 \\
\hline $\mathbf{c}_{\mathbf{5}}$ & 0,565 & 0,592 & 0,588 & 0,658 & 1,025 & 0,607 \\
\hline $\mathbf{c}_{\mathbf{6}}$ & 0,518 & 0,496 & 0,553 & 0,565 & 0,607 & 0,856 \\
\hline
\end{tabular}

Table 4: Coefficient matrices of correlation of various parameters of job satisfaction

\begin{tabular}{|l|c|c|c|c|c|c|}
\hline & $\mathbf{c}_{1}$ & $\mathbf{c}_{\mathbf{2}}$ & $\mathbf{c}_{\mathbf{3}}$ & $\mathbf{c}_{\mathbf{4}}$ & $\mathbf{c}_{5}$ & $\mathbf{c}_{\mathbf{6}}$ \\
\hline $\mathbf{c}_{\mathbf{1}}$ & 1,000 & & & & & \\
\hline $\mathbf{c}_{\mathbf{2}}$ & $\mathbf{0 , 4 8 3}$ & 1,000 & & & & \\
\hline $\mathbf{c}_{\mathbf{3}}$ & 0,628 & 0,518 & 1,000 & & & \\
\hline $\mathbf{c}_{\mathbf{4}}$ & 0,661 & 0,493 & $\mathbf{0 , 7 4 7}$ & 1,000 & & \\
\hline $\mathbf{c}_{5}$ & 0,520 & 0,618 & 0,566 & 0,594 & 1,000 & \\
\hline $\mathbf{c}_{\mathbf{6}}$ & 0,521 & 0,567 & 0,582 & 0,558 & 0,647 & 1,000 \\
\hline
\end{tabular}

In the entire sample of examinees the strongest positive correlations between satisfaction with the progress in the hierarchy and satisfaction by rewarding stimulus (correlation coefficient, $\rho=$ 0.747) is observed. The weakest mutual relationship is observed between income satisfaction and satisfaction with the cooperation with the associates $(\rho=0.483)$. After determining the mutual relationship of evaluations of various parameters of satisfaction for the entire sample and for individual companies included in the research (given in appendix), the interrelationships of the individual parameters of satisfaction and overall satisfaction using the same methodology are explored (Tabe 5. and 6).

Table 5: Covariance matrices of evaluations from the parameters of individual satisfaction and overall satisfaction

\begin{tabular}{|l|c|c|c|c|c|}
\hline & $\begin{array}{c}\text { Entire } \\
\text { sample }\end{array}$ & $\begin{array}{c}\text { PC } \\
\text { "Beograd put" }\end{array}$ & PC “PTT" & $\begin{array}{c}\text { Belgrade } \\
\text { Business school }\end{array}$ & $\begin{array}{c}\text { Other } \\
\text { Companies }\end{array}$ \\
\hline $\mathbf{c}_{\mathbf{1}}$ & 0,699 & 0,530 & 0,531 & 0,596 & 0,793 \\
\hline $\mathbf{c}_{\mathbf{2}}$ & 0,581 & 0,498 & 0,507 & 0,646 & 0,638 \\
\hline $\mathbf{c}_{\mathbf{3}}$ & 0,705 & 0,576 & 0,508 & 0,676 & 0,883 \\
\hline $\mathbf{c}_{\mathbf{4}}$ & 0,758 & 0,642 & 0,510 & 0,699 & 0,938 \\
\hline $\mathbf{c}_{\mathbf{5}}$ & 0,672 & 0,586 & 0,505 & 0,661 & 0,821 \\
\hline $\mathbf{c}_{\mathbf{6}}$ & 0,599 & 0,469 & 0,480 & 0,665 & 0,717 \\
\hline
\end{tabular}

\section{DISCUSSION}

The importance of building employees' satisfaction is often emphasized, because it is assumed that the spirit is essential to the functioning of the organization. Employees' satisfaction has three main effects- satisfaction and productivity; absence from work; fluctuations (Robbins and Coulter, 2005).

Dissatisfied workers have several ways to voice their discontent and dissatisfaction. Employees' responses to job dissatisfaction can be classified according to two dimensions: active - passive 
reaction and constructive - destructive one (Robbins, 2003). In this way, we obtain four types of employees' reactions to job dissatisfaction which deals with:

1. Abandonment - active-destructive responses, leaving the company due to dissatisfaction;
2. Neglect - passively letting the situation to get worse, increasing absence, reducing effort, increasing write-offs;

3. Protest - active-constructive efforts to remove the causes of discontent;

4. Loyalty - passive, constructive wait for things to improve.

Table 6: Coefficient matrix of correlation of the individual parameters and overall satisfaction (SZ)

\begin{tabular}{|l|c|c|c|c|c|}
\hline & $\begin{array}{c}\text { Entire } \\
\text { sample }\end{array}$ & $\begin{array}{c}\text { PC } \\
\text { "Beograd put" }\end{array}$ & PC “PTT" & $\begin{array}{c}\text { Belgrade } \\
\text { Business school }\end{array}$ & $\begin{array}{c}\text { Other } \\
\text { Companies }\end{array}$ \\
\hline $\mathbf{c}_{\mathbf{1}}$ & 0,796 & 0,797 & 0,738 & $\mathbf{0 , 7 2 5}$ & $\mathbf{0 , 8 1 8}$ \\
\hline $\mathbf{c}_{\mathbf{2}}$ & 0,751 & $\mathbf{0 , 7 9 2}$ & 0,750 & 0,747 & $\mathbf{0 , 7 0 0}$ \\
\hline $\mathbf{c}_{\mathbf{3}}$ & 0,840 & 0,851 & $\mathbf{0 , 7 6 4}$ & 0,776 & $\mathbf{0 , 8 6 5}$ \\
\hline $\mathbf{c}_{\mathbf{4}}$ & 0,847 & $\mathbf{0 , 8 9 3}$ & $\mathbf{0 , 7 7 9}$ & 0,809 & 0,818 \\
\hline $\mathbf{c}_{\mathbf{5}}$ & 0,812 & $\mathbf{0 , 8 5 2}$ & $\mathbf{0 , 7 5 1}$ & 0,794 & 0,848 \\
\hline $\mathbf{c}_{\mathbf{6}}$ & 0,792 & 0,804 & $\mathbf{0 , 7 2 3}$ & $\mathbf{0 , 8 3 0}$ & 0,789 \\
\hline
\end{tabular}

By the analysis of Table 6 the following correlations are observed in research results of companies in Serbia:

- Average evaluation of satisfaction with earnings is most strongly correlated with overall job satisfaction in the small private companies, whereas the weakest correlation has been found in Belgrade Business School. This result is explained by the fact that small businesses that are privately owned rated the factor of satisfaction as very low (basic needs are not met), while those who are employed in Belgrade Business School rated this factor with a high mark. For this reason, the management of small private companies should pay more attention to the factor of satisfaction with earnings as the primary determinants of overall satisfaction.

- Average evaluation of satisfaction with the cooperation with the associates is strongest correlated with overall job satisfaction in PC „Beograd put" , where the factor of job satisfaction was rated as the lowest of all surveyed companies, and the management of the company should work on communication and relationships with subordinates. The weakest correlations are observed in the group of small businesses, where employees, due to flatter hierarchical structure, provide better communication and closer relationships with co-workers.

- The strongest correlation of average evaluation of satisfaction with the possibility of advancement in the hierarchy with an overall satisfaction is observed in the group of small private companies, and the lowest in „, PTT“. In other words, the management of small private companies could pay greater attention to creating conditions of progress on the vertical hierarchy for the internally employed.

- Average evaluation of overall satisfaction with the system of rewarding stimulus is most closely correlated with overall satisfaction in PC „Beograd put“, while the weakest correlation was observed in „PTT“.

- Average evaluation of satisfaction with the cooperation with superiors is most closely correlated with overall satisfaction in PC „Beograd put“, while the weakest correlation was observed in „PTT“. For this reason, company „Beograd put" should, in order to increase the overall satisfaction of employees, improve the system of relations between employees and superiors.

- Average evaluation of satisfaction with job content is most closely correlated with overall satisfaction in Belgrade Business School, while the weakest correlation was observed in , PTT". For this reason, the management of Belgrade Business School needed to clearly define and improve the content of work in order to increase the overall satisfaction of employees.

\section{CONCLUSION}

Job satisfaction is a very important parameter, whose influence on the productivity and quality of work is dominant. This complex phenomenon involves attitudes about work that affect not only the motivation, but also the career, health and relationships with co-workers. Numerous studies have shown that job satisfaction depends not only on the nature of the work, but also on the expectations of the individual in relation to work. Generalizing carries a certain amount of risk with regard to the fact that there are various subjective 
factors and expectations in a variety of professions relevant to job satisfaction.

Job satisfaction of employees in the companies included in the sample has a large impact on the quality, effectiveness and operational efficiency. Besides the importance of customers and service users, professional satisfaction of respondents is directly related to the absence from work, interpersonal relationships and work organization. In large number of countries regular research on job satisfaction are conducted. Based on the data collected it is possible to identify gaps in work organization. Employees covered by the sample are faced with an increased risk of job dissatisfaction. Studies have shown that job satisfaction usually affects the following factors: gender, age, level of education, work experience, working conditions, wages, working hours and promotions.

\section{REFERENCES}

Bogetić, S., \& Ranđić, D. (2010). The role of knowledge productivity improvement in the process of SME competitive abilities. International Journal Total Quality Management \& Excellence, 38(1), 352-355.

Christensen, R. (1996). Analysis of Variance, Design, and Regression: Applied Statistical Methods. Boca Raton, FL: Chapman and Hall/CRC.

Fortune. 100 Best Companies to Work For, from http://money.cnn.com/magazines/fortune/best- companies/?iid=bc_sp_header

Greenberg, B., \& Baron, R. A. (1998). Behavior of people in organizations. Belgrade: Želnid.

Gregson, T. H. (1987). Factor Analysis of Multiplechoice Format for Job Satisfaction. Psychological Reports, 61(5), 747-750.

Lekić, S. (2010). The impact of organizational behavior on organizational commitment,. $\mathrm{PhD}$ thesis, Faculty of Management and Business Economics, Novi Pazar.

Lekić, S., Bogetić, S., \& Ranđić, D. (2011). Motivation impact on organizational commitment of employees in small and medium-sized enterprises. Paper presented at the Majska konferencija o strategijskom menadžmentu - Strategic managment 2011, Univerzitet u Beogradu, Tehnički fakultet u Boru, Zaječar, 26 - 28. maj 2011.

Robbins, S. (2003). Organizational Behavior. Englewood Cliffs, NJ: Prentice Hall Inc.

Robbins, S., \& Coulter, M. (2005). Management. Belgrade: Data Status.

Vidas-Bubanja, M. (2005). The role of knowledge and human capital in the modern techniques of ebusiness. In B. P. Inić (Ed.), Business Intelligencethe basis of successful management in global terms (pp. 107-123). Belgrade: Faculty of Trade and Banking.

Vidas-Bubanja, M. (2007) The effects of ICT on economic growth and employment. Economic views, No. 1/2007, Counselling Association of Economists Belgrade - Regional development and employment-essential elements of the national development strategy, Vrnjačka banja, 24-25 may 2007. 